\title{
UJI DAYA HAMBAT EKSTRAK DAUN SEMBUKAN (Paederia foetida) TERHADAP Vibrio cholerae
}

\section{THE INHIBITORY TEST OF SEMBUKAN LEAF (Paederia foetida) EXTRACT AGAINST THE GROWTH OF Vibrio cholerae}

\author{
${ }^{1}$ Adelya Fer Hidayat, ${ }^{2}$ Agus Selamet Duniaji*, ${ }^{2} \mathrm{Ni}$ Made Indri Hapsari Arihantana \\ ${ }^{1}$ Mahasiswa Program Studi Ilmu dan Teknologi Pangan, \\ Fakultas Teknologi Pertanian, Unud \\ ${ }^{2}$ Dosen Program Studi Ilmu dan Teknologi Pangan, Fakultas Teknologi Pertanian, Unud \\ Kampus Bukit Jimbaran, Badung-Bali
}

\begin{abstract}
Sembukan leaf (Paederia foetida) is one of a tropical Asian plant that contains bioactive compounds and often used as functional foods. The aim of this research was to determine the concentration of flavonoid compounds sembukan leaf (Paederia foetida) as well as the concentration of inhibitory against the growth of Vibrio cholerae. This study uses an experimental design with 5 kinds concentrations : $20 \%, 40 \%, 60 \%, 80 \%$, and $100 \%$, with three replications. The analysis were repeated 3 times resulting in 15 experimental units. The data were presented in descriptive statistic in the form of tables and figures. The results showed that the sembukan leaf extract contained flavonoid compounds of $1.18 \%$. The extract concentration of $80 \%$ exerted the highest inhibitory activity against $V$. cholerae classified as strong with a diameter zone inhibition of $19.60 \mathrm{~mm}$. The sembukan leaf has percentage inhibition in the range of $15.36 \%-64.86 \%$ with bacteriostatic category.
\end{abstract}

Keywords: paederia foetida, flavonoid, inhibitory, vibrio cholerae

\section{PENDAHULUAN}

Penelitian tentang tumbuhan kini telah banyak berkembang terutama dalam aktivitas biologis sebagai antioksidan dan antibakteri. Penelitian ini menjadi perhatian yang menarik dalam upaya penemuan senyawa baru yang bermanfaat bagi kesehatan dan manfaatnya dalam bidang pangan. Salah satu tanaman yang dimanfaatkan oleh sebagaian masyarakat sebagai makanan yang memiliki khasiat adalah daun sembukan (Paederia foetida). Daun sembukan merupakan salah satu bagian dari tanaman sembukan yang mengandung senyawa bioaktif.

Sembukan (Paederia foetida) atau yang sering disebut dengan daun kentut merupakan salah satu jenis pangan fungsional. Daun sembukan banyak dimanfaatkan oleh masyarakat daerah Jawa Timur untuk diolah menjadi makanan (pepes), lalapan, serta dapat dimanfaatkan sebagai obat diare, mengatasi maag, detoksifikasi (penawar racun), meningkatkan sel darah putih, obat cacing, pereda kejang, dan lain-lain (Nurcahyanti dan Wandra, 2012). Hal ini dikarenakan daun sembukan memiliki senyawa bioaktif seperti flavonoid, terpenoid, $\quad$ paedolone, $\quad \beta$-sitosterol, friedelin, campesterol, metil merkaptan dan senyawa aktif lainnya (Patel, 2017).

$$
\text { Anita et al., (2014) menyatakan }
$$
bahwa senyawa alkaloid, flavonoid, dan polifenol dapat berperan sebagai 
antimikroba. Senyawa bioaktif tersebut didapatkan dengan cara melakukan ekstraksi. Ekstraksi dapat dilakukan dengan metode maserasi yang merupakan salah satu metode yang paling efektif digunakan. Pelarut yang dapat digunakan untuk ekstraksi daun sembukan adalah etanol. Senyawa yang bersifat polar akan memudahkan penyerapan zat pada pelarut yang bersifat polar.

Vibrio cholerae adalah bakteri gram negatif berbentuk basil (batang) bengkok, bersifat aerob dan motil, serta mempunyai satu flagel kutub. Vibrio cholerae merupakan salah satu mikroba penyebab penyakit yang sering ditemukan pada makanan, biasanya Vibrio cholerae mencemari makanan yang berasal dari laut salah satunya pada kerang-kerangan. Bila bakteri ini mencemari makanan dan terkonsumsi dalam jumlah $10^{2}-10^{4}$ sel/gram, maka dapat menyebabkan penyakit kolera. Penghambatan ekstrak daun sembukan telah dilakukan oleh Uddin et al., (2007) yang menunjukkan bahwa ekstrak daun sembukan dapat menghambat Enterococcus faecallis, Staphylococcus aureus, Shigella flexneri, dan Escherichia coli. Metode yang digunakan untuk uji aktivitas antibakteri pada penelitian ini adalah metode difusi sumur dengan mengukur zona bening penghambatan pertumbuhan bakteri (Hermawan, 2007) dan metode kontak dengan menghitung jumlah kematian bakteri setelah diberi sejumlah zat antibakteri (Baron et al., 1992).
Berdasarkan data diatas maka penelitian ini perlu dilakukan untuk mengetahui ekstrak daun sembukan (Paederia foetida) untuk menghambat Vibrio cholerae menggunakan metode difusi sumur dan metode kontak.

\section{METODE PENELITIAN}

\section{Tempat dan Waktu Penelitian}

Penelitian ini dilakukan di Laboratorium Analisis Pangan, Sudirman dan UPT Laboratorium Terpadu Biosains dan Bioteknologi Universitas Udayana, Kampus Bukit Jimbaran. Pelaksanaan penelitian ini dilakukan pada bulan Juli 2019 sampai dengan September 2019.

\section{Bahan dan alat}

Bahan yang digunakan dalam penelitian ini adalah daun sembukan yang diperoleh dari Desa Baturiti, bakteri Vibrio cholerae yang diperoleh dari Bali Seafood Inpection Laboratory Sanur, Bali, etanol 96\%, aquades, LB (Lactose Broth), NA (Nutrient Agar), TCBS (Thiosulfat-sitratgaram empedu-sukrosa agar) (alkohol 95\%, $\mathrm{NaNO}_{2}, \mathrm{AlCl}_{3}, \mathrm{NaOH}$, dan metanol.

Alat yang digunakan dalam penelitian ini adalah blender, evaporator, water bath, spektrofotometer $U V$ Vis (biochrom), autoklaf, batang bengkok, timbangan analitik, mikropipet, freezer, inkubator (Memmert), tip, laminar flow cabinet (Kojair), bunsen, magnetic stirrer, tabung durham, kertas label, vortex, korek api, mikroskop, cawan petri (Pyrex), jarum 
ose, tabung reaksi (Pyrex), rak tabung reaksi, gelas beker (Pyrex), erlenmeyer (Pyrex), gelas ukur (Pyrex), jangka sorong, tabung effendorf, tissue, plastik HDPE (High density polyethylene), kertas saring, dan aluminium foil (Klin Park).

\section{Rancangan Penelitian}

Penelitian ini menggunakan metode eksperimental dengan perlakuan konsentrasi ekstrak daun sembukan (Paederia foetida), yaitu 20\%, 40\%, 60\%, $80 \%$, dan $100 \%$. Perlakuan ini diulang 3 kali. Data yangdiperoleh dianalisis menggunakan analisis deskriptif.

\section{Pelaksanaan Penelitian}

Tahap penelitian meliputi beberapa tahapan yaitu persiapan sampel, pembuatan ekstrak, uji kadar flavonoid, uji konfirmasi dan uji aktivitas antibakteri.

\section{Tahap Persiapan Sampel}

Persiapan sampel meliputi persiapan alat dan bahan, pada daun sembukan yang digunakan adalah daun yang berwarna hijau tua, selanjutnya dilakukan pengecilan ukuran sebesar $0,1 \mathrm{~cm}$ kemudian dilakukan pengeringan menggunakan oven dengan suhu $50^{\circ} \mathrm{C}$ hingga daun sembukan kering dan dapat diremas. Daun sembukan yang telah kering dihaluskan dengan blender dan diayak dengan ayakan 60 mesh hingga daun sembukan menjadi bubuk halus

\section{Tahap Pembuatan Ekstrak}

Pembuatan ekstrak daun sembukan dilakukan dengan menggunakan metode maserasi. Bubuk daun sembukan diambil sebanyak 100 gram lalu dimasukkan ke dalam etanol sebanyak 1 liter (1:10) dan didiamkan selama 72 jam. Setelah itu filtrat disaring menggunakan kertas saring sehingga didapatkan filtratnya kemudian dievaporasi pada suhu $40^{\circ} \mathrm{C}$ sampai tidak ada pelarut yang menetes lagi (Selawa et al., 2013 yang dimodifikasi).

\section{Pengujian Kadar Flavonoid Ekstrak}

\section{Daun Sembukan}

Pengujian kadar flavonoid dilakukan hanya pada ekstrak daun sembukan yaitu dianalisis dengan metode kalorimetri menurut $\mathrm{Xu}$ and Chang, 2007. Sebanyak $0,01 \mathrm{~g}$ sampel dilarutkan dalam $5 \mathrm{~mL}$ metanol, diambil $200 \mu \mathrm{L}$ lalu direaksikan dengan 2,5 mL aquades dan $0,15 \mathrm{~mL}$ $\mathrm{NaNO}_{2} \quad 5 \%$ kemudian divorteks dan didiamkan selama 5 menit. Sebanyak 0,3 $\mathrm{mL} \mathrm{AlCl}_{3}$ ditambahkan ke dalam larutan, kemudian didiamkan kembali selama 5 menit. Larutan direaksikan dengan $1 \mathrm{~mL}$ $\mathrm{NaOH}$ kemudian diencerkan dengan aquades hingga volume $5 \mathrm{~mL}$ lalu divorteks dan disentrifuse selama 5 menit, didiamkan selama 30 menit. Diukur absorbansi larutan pada panjang gelombang $510 \quad \mathrm{~nm}$ dengan spektrofotometer UV-Vis.

\section{Uji Konfirmasi}

Isolat Vibrio cholerae yang sudah disegarkan kemudian digores pada media TCBSA kemudian diinkubasi selama 24 jam dengan suhu $37^{\circ} \mathrm{C}$. Diambil satu koloni tunggal dan kemudian dimasukkan kedalam LB dan diinkubasi selama 24 jam 
pada suhu $37^{\circ} \mathrm{C}$. Setelah diinkubasi, dilakukan pewarnaan gram dan dilihat bentuk sel melalui mikroskop dengan pembesaran 1000 kali. Selanjutnya dilakukan uji katalase dengan memberikan $\mathrm{H}_{2} \mathrm{O}_{2}$ sebanyak 2 - 3 tetes dan diamati terbentuknya gas (Juniarthati, 2011).

\section{Pengujian Aktivitas Antibakteri}

\section{Dengan Metode Difusi Sumur}

Sebanyak $100 \mu \mathrm{L} \quad V$. cholerae disebar dalam media NA yang telah dipersiapkan. Media didiamkan \pm 15 menit kemudian dilubangi dengan tabung durham lalu diisi $\pm 20 \mu \mathrm{L}$ ekstrak etanol daun sembukan sesuai dengan perlakuan. Selanjutnya, diinkubasi pada suhu $37^{\circ} \mathrm{C}$ lalu zona penghambatan diukur dengan jangka sorong sebanyak empat kali di tempat yang berbeda dan hasilnya dirataratakan kemudian dikurangi dengan diameter sumur (mm).

\section{Pengujian Aktivitas Antibakteri}

\section{Dengan Metode Kontak}

Hasil penyegaran bakteri yang ditandai dengan adanya kekeruhan pada media LB dipipet $0,1 \mathrm{ml}$ bakteri ke dalam tabung reaksi, kemudian ditambahkan 0,1 ml ekstrak. Masing - masing tabung reaksi diinkubasi dengan perlakuan waktu inkubasi 24 jam. Setelah waktu inkubasi tercapai maka sebanyak $0,1 \mathrm{ml}$ ditanam dalam media NA (Nutrient Agar) dengan metode sebar kemudian diinkubasi selama 24 jam. Analisis hasil penghambatan dilakukan dengan menghitung indeks pertumbuhan relative (log $\mathrm{Nt} / \log \mathrm{No})$
(Tanzila, 2016).

\section{HASIL DAN PEMBAHASAN}

\section{Uji Kadar Flavonoid Ekstrak Etanol}

Daun Sembukan

Pengujian senyawa flavonoid ekstrak daun sembukan dilakukan secara kuantitatif. Kadar senyawa flavonoid yang didapat pada ekstrak daun sembukan sebesar $1,18 \%$ dengan menggunakan pelarut etanol 96\%. Pada penelitian Ekawati et al.,(2017) Identifikasi senyawa flavonoid dalam ekstrak daun sembukan telah dilakukan dengan menggunakan pelarut etanol $96 \%$ dengan hasil (+) positif mengandung senyawa flavonoid.

Etanol merupakan salah satu pelarut yang bersifat polar, menurut Moein dan Mahmood (2010), pelarut yang bersifat polar mampu melarutkan fenol lebih baik, dimana turunan fenol tertinggi adalah flavonoid. Kemungkinan tingkat kepolaran flavonoid dengan kepolaran etanol sama. Pada umumnya pelarut yang banyak digunakan adalah etanol karena etanol mempunyai polaritas yang tinggi sehingga dapat mengekstrak bahan lebih banyak dibandingkan jenis pelarut lain. Sejalan dengan pendapat Sudarmadji (2003) bahwa etanol dapat mengekstrak senyawa aktif yang lebih banyak dibandingkan jenis pelarut organik lainnya. 


\section{Uji Konfirmasi Vibrio cholerae}

Pengujian konfirmasi pada Vibrio cholerae meliputi bentuk koloni, warna koloni, pewarnaan gram, pengamatan bentuk sel dan pengujian katalase. Bentuk koloni $V$. cholerae adalah bulat. Menurut Khariri (2013) V. cholerae memiliki morfologi koloni yang besar dengan diameter $<3 \mathrm{~mm}$, bulat, permukaan yang halus, agak datar, bagian tengah buram dan bagian pinggir terang, berwarna kuning pada media TCBSA. Pada warna koloni $V$. cholerae akan mengubah media selektif TCBSA yang berwarna hijau menjadi warna kuning. Hal ini sesuai dengan Widyastana dan Yogi (2015) bahwa pada sampel yang positif tercemar $V$. cholerae menunjukkan hasil koloni berwarna kuning pada media TCBS Agar. Pengamatan warna dan bentuk koloni dapat dilihat pada Gambar 1.

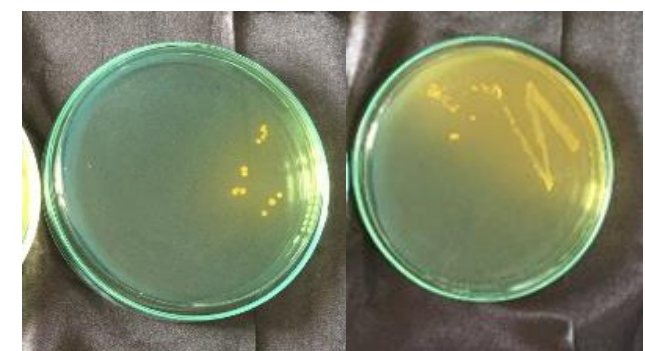

Gambar 1. Bentuk dan warna koloni $V$. cholerae pada TCBS Agar

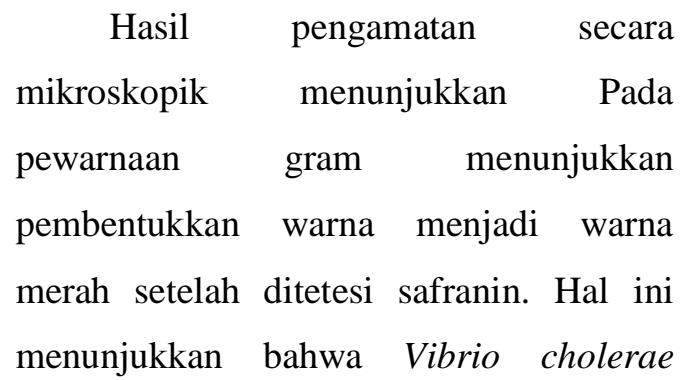

merupakan bakteri gram negatif, sesuai dengan Karmana (2008) yang menyatakan bahwa karena telah kehilangan warna ungu, bakteri Gram negatif akan berikatan dengan safranin dan berwarna merah.

Bentuk sel pada Vibrio cholerae menunjukkan bentuk basil (batang) pendek yang agak bengkok. Menurut Amelia (2005) Vibrio cholerae merupakan bakteri gram negatif dengan ukuran panjang 2-4 $\mu \mathrm{m}$ dan berbentuk batang bengkok seperti koma. Hasil pengamatan pewarnaan gram dan bentuk sel $V$. cholerae dengan menggunakan mikroskop pembesaran 200x dapat dilihat pada Gambar 2.

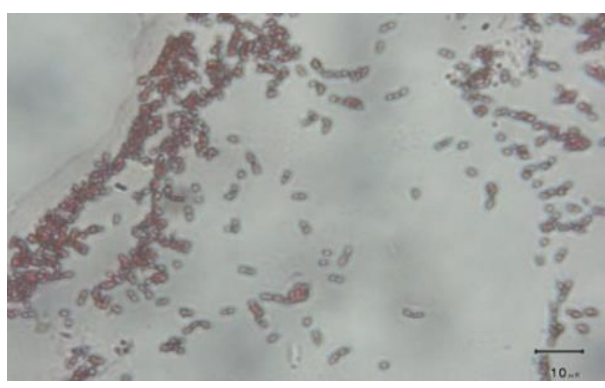

Gambar 2. Morfologi V. cholerae

Uji katalase dilakukan sebagai salah satu dari sifat uji konfirmasi. Uji positif ditandai dengan adanya pembentukan gelembung gas. Pada koloni awal dari kultur $V$. cholerae yang telah ditumbuhkan pada media LB, menunjukkan hasil positif (terbentuknya gelembung gas). Hal ini sesuai dengan Herwandi et al., (2019) bahwa V. cholerae menunjukkan hasil positif pada pengujian katalase. 
Akivitas Antibakteri Ekstrak Daun Sembukan (Paedria foetida) Terhadap Pertumbuhan $V$. cholerae dengan Metode Difusi Sumur

Tabel 1. Penghambatan ekstrak daun sembukan terhadap $V$. cholerae

\begin{tabular}{cc}
\hline Konsentrasi & $\begin{array}{c}\text { Rata-Rata } \\
\text { Penghambatan } \\
(\mathrm{mm})\end{array}$ \\
\hline $20 \%$ & 15,36 \\
$40 \%$ & 17,13 \\
$60 \%$ & 18,33 \\
$80 \%$ & 19,60 \\
$100 \%$ & 14,46 \\
\hline
\end{tabular}

Menurut Davis and Stout, kategori daya hambat pada diameter penghambatan dibagi menjadi empat kategori, yaitu $<5$ $\mathrm{mm}$ lemah, 5-10 $\mathrm{mm}$ sedang, 10-20 $\mathrm{mm}$ kuat, dan >20 $\mathrm{mm}$ sangat kuat. Berdasarkan Tabel 1 dapat diketahui ratarata penghambatan ekstrak daun sembukan terhadap pertumbuhan $V$. cholerae, dimana ekstrak daun sembukan sudah mampu menghambat pertumbuhan $V$. cholerae dengan kategori kuat dari konsentrasi terendah hingga tertinggi dengan rata-rata diameter penghambatan $14,46 \mathrm{~mm}-19,60 \mathrm{~mm}$.

Menurut Maleki et al., (2008), konsentrasi ekstrak yang terlalu pekat menyebabkan ekstrak sulit berdifusi secara maksimal ke dalam medium yang mengandung inokulum. Rata-rata diameter penghambatan dengan kategori kuat dipengaruhi oleh kandungan flavonoid yang terdapat pada daun sembukan sebesar 1,18\%. Senyawa flavonoid berperan sebagai antibakteri sejalan dengan Anita et al., (2014) yang menyatakan senyawa alkaloid, flavonoid, dan polifenol dapat berperan sebagai antimikroba. Senyawa antibakteri yang dimiliki ekstrak daun sembukan dapat melakukan penghambatan dengan cara membentuk senyawa kompleks dengan membran sel melalui ikatan hidrogen sehingga dapat merusak permeabilitas dinding sel bakteri (Ramadhan et al., 2015) Gambar zona hambat ekstrak daun sembukan terhadap Vibrio cholerae dapat dilihat pada Gambar 3 .

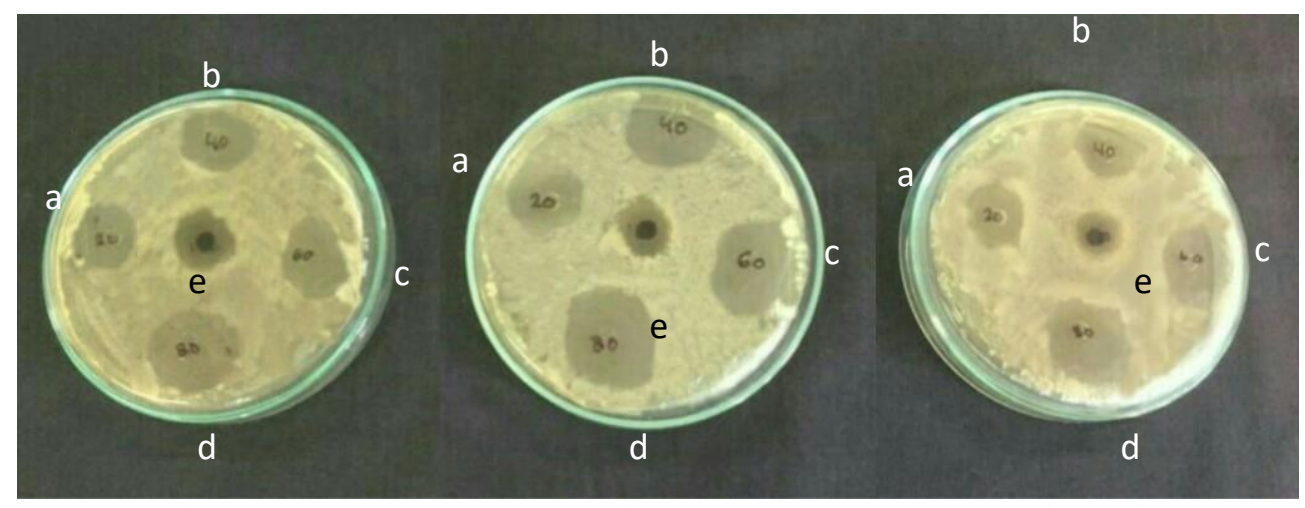

Gambar 3. Zona hambat ekstrak daun sembukan terhadap Vibrio cholerae (a:20\%, b:40\%, c:60\%, d:80\%, e: $100 \%)$ 


\section{Akivitas Antibakteri Ekstrak Daun Sembukan (Paederia foetida) Terhadap Pertumbuhan Vibrio cholerae dengan Metode Kontak}

Tabel 2. Penghambatan Ekstrak Daun Sembukan Terhadap V. cholerae Dengan Metode

\begin{tabular}{|c|c|c|c|c|}
\hline Konsentrasi & $\begin{array}{c}\text { Jumlah bakteri } \\
\text { sebelum } \\
\text { dikontakkan } \\
(\mathbf{C f u} / \mathrm{ml})\end{array}$ & $\begin{array}{c}\text { Jumlah bakteri } \\
\text { sesudah } \\
\text { dikontakkan } \\
(\mathrm{Cfu} / \mathrm{ml})\end{array}$ & $\begin{array}{c}\text { Penurunan } \\
\text { jumlah } V . \\
\text { cholerae } \\
(\text { Cfu/ml })\end{array}$ & $\begin{array}{c}\text { Persentase } \\
\text { kematian } \\
(\%)\end{array}$ \\
\hline $20 \%$ & $1,48 \times 10^{5}$ & $1,20 \times 10^{5}$ & $0,28 \times 10^{5}$ & 18,91 \\
\hline $40 \%$ & $1,48 \times 10^{5}$ & $0,97 \times 10^{5}$ & $0,51 \times 10^{5}$ & 34,23 \\
\hline $60 \%$ & $1,48 \times 10^{5}$ & $0,71 \times 10^{5}$ & $0,77 \times 10^{5}$ & 52,02 \\
\hline $80 \%$ & $1,48 \times 10^{5}$ & $0,52 \times 10^{5}$ & $0,96 \times 10^{5}$ & 64,86 \\
\hline $100 \%$ & $1,48 \times 10^{5}$ & $1,25 \times 10^{5}$ & $0,23 \times 10^{5}$ & 15,36 \\
\hline
\end{tabular}

Berdasarkan Tabel 2 menunjukkan persentase kematian $V$. cholerae tertinggi sebesar $64,86 \%$ pada konsentrasi $80 \%$, persentase kematian $V$. cholerae terendah sebesar $15,36 \%$ pada konsentrasi $100 \%$. Total $V$. cholerae yang digunakan pada penelitian ini ada $1,48 \times 10^{5} \mathrm{CFU} / \mathrm{ml}$. Pada konsentrasi $100 \%$ penurunan jumlah $V$. cholerae terjadi karena konsentrasi ekstrak yang lebih tinggi mengakibatkan terjadinya kejenuhan sehingga menyebabkan senyawa-senyawa aktif yang terkandung di dalam ekstrak tidak terlarut dengan sempurna (Maleki et al., 2008). Hal ini yang menyebabkan pada konsentrasi tertinggi $100 \%$ mengalami sedikit penurunan pada jumlah $V$. cholerae setelah dikontakkan. Brooks et al., (2013) menyatakan bahwa aktivitas antibakteri dipengaruhi beberapa faktor yaitu konsentrasi ekstrak, kandungan senyawa antibakteri, daya difusi ekstrak dan jenis bakteri yang dihambat.
Menurut Baron et al., (1992), jika kematian bakteri uji minimal 99,99\%, maka pada konsentrasi tersebut antibakteri dikatakan bersifat bakterisidal (membunuh bakteri). Sebaliknya, jika kematian kurang dari 99,99\%, maka antibakteri dikatakan bersifat bakteristatik (menghambat pertumbuhan bakteri). Dilihat dari persentase kematian, ekstrak daun sembukan memiliki daya penghambatan kurang dari 99,99\%. Pada penelitian ini ekstrak daun sembukan bersifat bakteristatik karena memiliki penghambatan kurang dari 99,99\%.

\section{KESIMPULAN DAN SARAN}

\section{Kesimpulan}

1. Ekstrak daun sembukan (Paederia foetida) mengandung total flavonoid sebesar $1,18 \%$

2. Konsentrasi optimum $80 \%$ untuk menghambat pertumbuhan $V$. cholerae adalah pada dengan 
diameter penghambatan $19,6 \mathrm{~mm}$ dengan kategori kuat.

3. Konsentrasi ekstrak daun sembukan $80 \%$ membentuk efek bakteristatik tertinggi sebesar $64,86 \%$.

\section{Saran}

Perlu dilakukan uji kuantitatif senyawa fitokimia lain pada ekstrak daun sembukan (Paederia foetida) dan uji daya hambat dengan bakteri yang lain

\section{DAFTAR PUSTAKA}

Amanah, N. 2011. Identifikasi dan karakterisasi substrat antimikroba dari bakteri asam laktat kandidat probiotik yang diisolasi dari dadih dan yoghurt. Skripsi. Fakultas Peternakan. Institut Pertanian Bogor

Amelia, S. 2005. Vibrio cholerae. Departemen Mikrobiologi. Skripsi. Fakultas Kedokteran. Universitas Sumatera Utara. Medan

Anita, A., S. Khotimah, dan A. H. Yanti. 2014. Aktivitas antibakteri ekstrak daun jambu air (Dendropthoe pentandra L. Miq) terhadap pertumbuhan Salmonella typhi. Skripsi. Universitas Tanjungpura. Pontianak

Atikah, N. 2013. Aktivitas antimikroba ekstrak herba kemangi (Ocimum americanum L) terhadap Staphylococcus aureus dan Candida albicans. Skripsi. UIN Syarif Hidayatullah. Jakarta.

Baron, E.J., L.R Peterson, dan S.M. Finegold. 1992. Diagnostic Microbiology. 9th Ed. Baile \& Scott's. St. Louis

Brooks, G.F., K. Carroll., J.S Butel., dan Jawetz, Melnick. 2013.
Adelberg`s

Microbiology.

Philadelphia:

Company Inc.

Davis, W.W., dan T.R. Stout. 1971. Disc plate method of microbiological antibiotic assay, appl. Microbiol. 4 (22), 666-670

Djajadisastra, A.N. 2007. Penapisan komponen antibakteri dan uji toksisitas dari spons perairan Taka Bonerate Sulawesi Selatan. Skripsi. Bogor. Program Studi Teknologi Hasil Perikanan Fakultas Perikanan dan Ilmu Kelautan Universitas Institut Pertanian Bogor

Ekawati, A.M., I.W Suirta dan S.R Santi. 2017. Isolasi dan identifikasi senyawa flavonoid pada daun sembukan (Paederia foetida) serta uji aktivitasnya terhadap antioksidan. Skripsi. Universitas Udayana. Bali

Farouque, S. M., M. J. Albert., dan J. J. Mekalanos. 2000. Epidemiology, Genetiks and Ecology of Toxigenic Vibrio cholerae. Microbiology and Molecular Biology Reviews, 62 (4) :13011314

Hermawan, A. 2007. Pengaruh ekstrak daun sirih (Piper betle L.) terhadap pertumbuhan Staphylococcus aureus dan Escherichia coli dengan Metode Difusi Disk. Skripsi. Universitas Airlangga, Surabaya.

Herwandi., Mahyarudin., dan Effiana. 2019. Uji aktivitas antibakteri ekstrak etanol annona muricata terhadap Vibrio cholerae. Skripsi. SUniversitas Tanjungpura. Pontianak

Juniarhati, P. E. 2011. Skrining bakteri asam laktat isolat susu sapi Bali penghasil bakteriosin penghambat 
bakteri patogen Escherichia coli Penyebab Diare Akut. Skripsi. Jurusan Farmasi. Unversitas Udayana. Bali

Maleki, S., S.M, Seyyenejad, dan H, Motamedi. 2008. antibacterial activity of the aluid of iranian torilis leptophylla against some clinical pathogen. Pakistan Journal of Biologycal Science. Vol.11(9), 1286-1289

Mardigan, M. T., Martinko, J.M, dan Parker, J. 2000. Biology of Microorganisms. 8th edition. Pearson Prentice Hall. USA.

Misna., D, Khusnul. 2016. Aktivias antibakteri ekstrak kulit bawang merah (Allium cepa L. terhadap bakteri Staphylococcus aureus. Galenika Journal of Pharmacy. Vol. 2 (2): 138 - 144.

Moein S., dan Mahmood RM. 2010. Relationship between antioxidant properties and phenolics in Zhumeria majdae. Journal of Medicinal Plants Research (7): 517-521

Nurcahyanti, A.D.R dan Wandra, J. 2012. Sembukan kurang sedap namun berkhasiat hebat. Bios : Salatiga

Oman, K. 2008. Biologi. Jakarta: PT Grafindo Media Pratama (halaman :56)

Patel D.K. 2017. Paederia Foetida Linn.: A Potential climbing medicinal herb in central india. international journal of environmental sciences \& natural resources. Vol: 6(5):0107

Prayoga, D. 2013. Perbandingan efek ekstrak daun sirih hijau (Piper betle L.) dengan metode difusi disk dan sumuran terhadap pertumbuhan bakteri staphylococcus aureus. Skripsi Program Studi Pendidikan Dokter Fakultas Kedokteran dan Ilmu
Kesehatan Universitas Islam Negeri Syarif Hidayatullah. Jakarta

Ramadhan, N.S., R. Rasyid., E. Sy. 2015. Daya hambat ekstrak daun pegagan (Centella asiatica) yang diambil di batusangkar terhadap pertumbuhan Vibrio cholerae secara In Vitro. Jurnal Kesehatan Andalas. Fakultas Kedokteran. Universitas Andalas. Padang. Vol.4(1)

Sudarmadji, S. 2003. Analisa bahan makanan dan pertanian. Edisi ke2.Liberty.Yogyakarta.Vol:III

Sunatmo, T. I. 2007. Eksperimen Mikrobiologi Dalam Laboratorium. Penerbit Ardy Agency. Bogor.

Selawa, W., M,R,J. Runtuwene, dan G. Citraningtyas. 2013. Flavonoid dan kapasitas antioksidan total ekstrak etanol daun binahong (Andredera Cordifulic Ten Steenis.) FMIPA. Skripsi. Universitas Samratulangi. Manado

Tanzila, A., P.A, Sandhi, dan N.N Puspawati 2016. Kemampuan daya hambat ekstrak daun pegagan (Cantella asiatica L.)Urban terhadap pertumbuhan Escherchia coli ATCC 8739. Skripsi. Jurusan Ilmu dan Teknologi Pangan. Universitas Udayana. Bali

Uddin, B., Nahar, T., Khalil, M.I dan Hossain, S 2007. In vitro antibacterial activity of the ethanol extract of paederia foetida (Rubbiccae) leaves. Bangladesh Journal Life Science. Vol.19.141143

Widyastana, dan I.W Yogi. 2015. Keberadaan bakteri patogen Vibrio cholerae pada beberapa hasil perikanan yang dijual di pasar tradisional kota denpasar. Tesis. Program Magister. Program 
Studi Biologi. Program Pasca Sarjana. Universitas Udayana. Denpasar

Xu, B.J. dan S.K.C Chang. 2007. A comparative study on phenolic profiles and antioxidant activities of legumes affected by extraction solvent. Journal of Food Science. Vol.72: 59-66 